\title{
The Implementation of Business and Human Rights Principles to Palm Oil Companies in Aceh Province
}

\author{
Khairani Arifin ${ }^{1, *}$ Safrina Safrina ${ }^{1}$ \\ ${ }^{I}$ Faculty of Law Syiah Kuala University, Centre of Human Rights Syiah Kuala University, Darussalam Banda \\ Aceh, Indonesia \\ *Corresponding author. Email: khairaniarifin@unsyiah.ac.id
}

\begin{abstract}
Since 2011, the United Nations Guiding Principles on Business and Human Rights (UNGPs) have been endorsed by the UN Human Rights Council, and Indonesia has also agreed to implement the guide by issuing the "Principles of Business and Human Rights". This guide was prepared with concerns about business practices that are increasingly widespread and have the potential to worsen communities and environmental conditions. In this principle, in addition to pursuing profit, the business activities should be an effort for the welfare of every individual without discrimination, not hurting and not causing harm. However, currently, Business and Human Rights Principles have not been implemented properly by companies, especially plantation companies. This study aims to examine the implementation of the principles by palm oil companies in Aceh Province and to find out the government's efforts to ensure the implementation of the 3 pillars of the business and human rights principles. This is a qualitative research with an empirical juridical approach. The results show that palm oil companies have not applied the principles of business and human rights in running their business. The various policies issued by the company have not explicitly regulated the principles, both in the pillar of respect and the pillar of recovery. The local government has not made specific efforts to ensure companies implement these principles. In addition, it is recommended that companies begin to formulate policies that firmly incorporate business and human rights principles and the government must supervise and develop companies that run business in Aceh province, especially palm oil companies, to apply business and human rights principles in carrying out their business.
\end{abstract}

Keywords: business and human rights, palm oil company.

\section{INTRODUCTION}

In 2011, Indonesia approved the United Nations Guiding Principles on Business and Human Rights (UNGPs). Subsequently, at the G20 Countries meeting, in which Indonesia is a member, the countries' leaders declared they would work to build a suitable policy framework in each country. These policies included the National Action Plan on Business and Human Rights and affirmed the businesses' responsibility to carry out an audit (due diligence) of Human Rights (HAM)[1]. As one of the UN Human Rights Council member states that also pushed for the passing of the Resolution on the UNGPs, Indonesia certainly has more moral ties to implement the UNGPs. Moreover, Indonesia is actively involved in encouraging the birth of a Resolution on Legally Binding Instruments, which aims to formulate legal instruments that are binding at the international level, so that companies can no longer avoid their obligations to respect and fulfill human rights. One of the United Nations researchers, John Ruggie, found that business can harm all aspects of human rights. Those aspects included fulfilling the right to education, up to forcible transfers, and gross human rights violations such as torture. For this reason, according to Ruggie in 2008, the UNGPs is compiled based on concerns about business practices that are increasingly widespread and can worsen community and environmental conditions. In UNGPs, companies are required to get profit, and business activities carried out by the company should be a step for every individual's welfare without discrimination, not hurting, and not causing harm[2]. The Principles of Business and Human Rights also state that companies must respect 
internationally recognized human rights, even if national legal system does not recognize them. They need to respect all internationally recognized human rights, which includes the Universal Declaration of Human Rights[3]. Seeing the reality today in Indonesia, companies are increasingly playing an important role in people's lives, especially in the economic field. Companies in the modern world have an important role in economic life which has many functions, namely employers, producers, price fixers, foreign exchange users, and others[4]. However, in carrying out their business, many things are alarming.

One of the most alarming businesses in Indonesia is the oil palm plantation, which continues to cause problems and violates human rights principles, either related to labor conditions, pollution and environmental destruction, and agrarian conflicts. From an economic point of view, palm oil is indeed a strategic commodity because it contributes to Indonesia's largest foreign exchange, such as in Aceh where the palm oil industry supports $30 \%$ of economic growth. According to data published on the Aceh Agriculture and Plantation Service's website, the total area of oil palm plantations in Aceh Province in 2017 was 421,820 hectares consisting of $220,092 \mathrm{Ha}$ or $27.06 \%$ of People's Plantations and 201,728 Ha or $10.46 \%$ belonged to Large Plantations. There was an increase of $65,976 \mathrm{Ha}$ or $18.54 \%$ compared to 2010 which covered 355,844 Ha, consisting of 173,217 Ha of People's Plantations and 182,627 Ha of Large Plantations. The increase in area was due to the Sustainable Palm Oil Development program's implementation and the public's high interest in developing Palm oil. Currently, there are 61 oil palm plantation companies registered in Aceh Province. Of these, 39 of them are still operating, eight are under construction, and 14 companies are no longer running.

With this number, besides improving the regional economy, the increase in palm oil plantation areas also contributes to various human rights violations. For example, in 2015, based on Walhi Aceh report in Aceh Singkil, 15 oil palm plantation companies were operating in Aceh Singkil. The amount of oil palm production in Aceh Singkil reached 355,366 tons per year. This condition had no impact on reducing the poverty of palm oil workers in Aceh Singkil and the economy of communities living around the palm oil plantations. The management of plantations harms the economy, society, and ecology, including agrarian conflicts[5]. Regarding agrarian conflicts related to oil palm plantations, the Legal Aid Institute $(\mathrm{LBH})$ noted that in 15 provinces, the area of land conflict in 2018 reached 338,280.47 hectares. As many as 5,420.5 hectares of the total figure was located within Aceh Province. Also, LBH Aceh has assisted 58 residents of Nagan Raya and Aceh Tamiang who were in conflict with large plantation companies. Twenty-three of them were made suspects for seizing other people's land or illegally entering other people's properties [6].

The description above shows that the plantation business still causes many problems. Therefore, it is essential to research how plantation companies in Aceh implement business and human rights principles. This study aims to see how business principles and human rights are applied by plantation companies in carrying out their business operations, both internally and externally.

\section{RESEARCH METHOD}

This research is qualitative research with the empirical juridical approach. Field research to obtain supporting data from respondents and research informants were conducted by interviewing parties related to the implementation of business and human rights principles, including plantation companies, relevant government bodies, workers, and the community. For this purpose, an interview guide was prepared.

The research locations were Aceh Tamiang, Nagan Raya, and Aceh Singkil. These districts have the largest number of palm oil plantation companies, the widest plantation, and the largest number of palm oil workers. They can represent other areas with similar characteristics. The selection of locations with different features is expected to provide different nuances in observing the application of Business and Human Rights principles by palm oil plantation companies. At the same time, the research samples involved the director or manager of law or public relations at plantation companies in Aceh Tamiang, Nagan Raya and Singkil, Department of Agriculture and plantations and Department of Environment and Forestry at the provincial level and district level, NGOs, traditional leaders and workers in the company plantations, and communities living around the plantation. All data collected, both legal literature and field data were sorted based on the main problem or research question that will be answered. Written legal materials and the results of field interviews were interpreted, analyzed, and presented qualitatively. 
The research framework is as follow:

\section{FINDINGS AND DISCUSSION}

Since 2008, Professor John Ruggie, the special representative of the UN Secretary-General for Business and Human Rights (HAM) issues, has formulated the Three Pillars framework, namely: protect, respect, and remedy. The Three Pillar Principles were adopted by the UN Human Rights Council through a resolution in June of 2011, under the United Nations Guiding Principles on Business and Human Rights ('UNGPs')[7].

The UNGPs resolution is the only international instrument that guides protecting human rights in business activities. Therefore, the UNGPs guide on how governments and corporations should take positions and act in business and human rights relations. The 'regulatory gap' problem, according to John Ruggie, can be solved through the Three Pillars framework above. The first pillar is the government's obligation to protect. This pillar reaffirms the government's obligation as the main obligation bearer in the protection, respect, and fulfillment of human rights. Through regulation and legislation, the government must ensure that business activities by corporations do not violate human rights. This pillar also provides that the government carries out its obligations, as stated in the international conventions and agreements that have been ratified.

The second pillar contains a breakthrough to encourage business actors to make human rights part of their business. This pillar uses a more refined language for business, namely corporate responsibility to respect human rights. Responsibility is used as a middle way for the corporation to accept this guide. Corporations are asked to be responsible for avoiding human rights violations.

UNGPs guides how companies avoid committing human rights violations through the knowing and showing mechanism. To prevent human rights violations, corporations are expected to know the impact that their business activities can have on human rights and show the public what steps have been taken. This knowing and showing mechanism can effectively solve regulatory gap issues in business and human rights relations[8]. As explained above, business actors feel that they have fulfilled their obligations if they have implemented the applicable regulations. For example, business actors pay labor wages following government regulations; as a result, the business actor is not bound by other responsibilities, even though, for instance, it turns out that the wages paid for workers are still below the minimum wage for a decent living. By knowing and showing, companies are expected to know that their workers are still getting wages below the standard of living. Therefore, companies can take the necessary steps to avoid human rights violations, and their business activities can be sustainable. UNGPs also provide complete guidance on how companies can avoid human rights violations through this knowing and showing mechanism[9]. Corporations should conduct Human Rights Due Diligence or human rights audits. Before performing this audit, corporations need to commit to respecting human rights. Furthermore, the corporation can assess the impact of its business activities on human rights.

The Guiding Principles for Business and Human Rights establish norms based on principles of international law and social expectations, providing the foundation for future rule-making by states at the national and global level, and an authoritative framework for ethical business conduct will be judged from this point forward. These guiding principles consist of three different but interrelated pillars[10]:

1. The state's obligation to protect human rights, in which the government must protect individuals from human rights violations by third parties, including businesses;

2. Company's responsibility to respect human and community rights may be implemented by not violating internationally recognized human rights by avoiding, reducing, or preventing negative impacts of company operations;

3. The need to expand access for victims to receive effective recoveries, both through judicial and non-judicial mechanisms.

Based on these three pillars, the corporation or company must incorporate these guiding principles into its business operations. It is due to the fact that these guiding principles have provided global standards for corporations on how they must respect and protect human rights that apply in a country where the corporation operates[11]. So applying these business and human rights principles can be a means for companies to reduce or avoid human rights violations, which in turn will also reduce claims and risks to the company[12]. 
Based on the copy of the UNGPs BHR obtained and discussed in the previous chapter, three important pillars play a role: Government, corporations or companies, and recovery. There are 31 principles formulated in the UNGPs relating to the three pillars: 10 principles for Government obligations, 14 for companies, and 7 for access to recovery. The formulation of the UNGPs BHR principles also contains comments on each of the regulations. The beginning of the Guiding Principles document lists three general principles. The three general principles. They are:

1. The state's obligation to respect, protect and implement human rights and fundamental freedoms;

2. The role of a business company as a particular party in society that carries out its unique functions needs to be adjusted to the prevailing laws and respect for human rights; and

3. The need to regulate rights and obligations which are in line with adequate and appropriate recovery when human rights violations occur

\subsection{Implementation of Business and Human Rights Principles by Oil Palm Plantation Companies in Aceh}

Based on data from the Aceh Agriculture and Plantation Service, as of 2019, the area of oil palm plantations in Nagan Raya was 71,661.53 hectares, Aceh Singkil 43,910.13 hectares, and Aceh Tamiang 51,183.73 hectares[13]. With the broad area of oil palm plantations in these three areas, besides having an economic impact on the companies and local governments, it also harms the community and the environment. Therefore, it is essential to ensure that oil palm companies pay attention to aspects of human rights in running their business by referring to the Business and Human Rights principles stated in the UNPGs, which Indonesia is among the signatory countries.

The implementation of the Business and Human Rights Principles will be analyzed based on the two pillars listed in the UNGPs, namely the Pillars of Respect and the Pillars of Recovery in 4 Oil Palm Plantation Companies in Aceh Tamiang, Nagan Raya, and Singkil. There are still many principles of Business and Human Rights, as stated in the UNGPs that have not been implemented by the companies, both the principles stated in the pillar of respect and the pillar of recovery. In the second pillar, in principles 12 to 16 , it is noted that business companies must avoid violations of the human rights of others and must overcome human rights consequences that can be detrimental when running their business. In other words, a company is obliged to carry out its business activities by not being involved with or not harming others' human rights: employees, community members, consumers, and others.

Companies' responsibility for respecting human rights requires companies to properly understand all international human rights standards and norms, as confirmed in the International Bill of Human Rights, international human rights instruments, and instruments on standards and protection of workers' rights published by the ILO. Companies must also avoid the negative impacts of their business activities on vulnerable groups, such as children, women, indigenous people, people with disabilities, and migrant workers and their family members. The responsibility to respect human rights mandates the companies to avoid occurring or being involved in adverse impacts on human rights, either on their business activities, products, and services, through their activities or business relationships with other parties. The company's responsibility to respect human rights applies fully and equally to all business enterprises regardless of their size, sector, context of activity, ownership, and structure. On this basis, companies must know and be able to demonstrate that they respect human rights by:

a. Establishing policy commitments that support the responsibility to respect human rights;

b. Carrying out human rights due diligence on an ongoing basis to identify, prevent, mitigate and quantify the impact of human rights;

c. Having processes that allow remediation and reduce the human rights for their business activities and contribution.

\subsection{A commitment of Policy Makers in the Company}

Based on the research results in five palm oil companies located in Aceh Tamiang, Nagan Raya, and Aceh Singkil, various policies are available and applicable to the research object companies, both internal company policies, and external policies. Internal policies consist of policies related to the fulfillment and protection of labors' rights. In contrast, external policies are policies to fulfill the rights and protection of the community and the environment. 


\subsubsection{Labors' Protection Policy}

The palm oil companies, as the research object, have average labor of more than 100 people. The provisions concerning labors as stipulated in Law No. 13 of 2003 must be the guideline in managing them. The labours' rights that must be the company's attention are those contained in articles 77 to 79 , namely:

1) Special rights for women to get maternity leave, menstrual leave, protection during pregnancy, miscarriage leave, and delivery costs.

2) The right to become a member of a labor union;

3) The right to Social Security and K3 (Occupational Safety and Health)

4) The right to Receive Fair Wages;

5) The right to Limitation of Working Time, Rest, Leave \& Holiday;

6) The right to participate in agreeing to the work agreement.

7) The right to protect unfair dismissal decisions

The number of permanent labors working in the five companies in Aceh Tamiang, Nagan Raya, and Singkil District was 507 people. There were only 33 women, whereas 474 labors were male. From the permanent labors working in five companies showed that the number of working men far more than women. With the insignificant number of women labors, the company did not make specific policies for the benefit of women labors. The differences in treatment only occurred in terms of maternity, delivery leave, and provision of health services during childbirth[14]. However, other policies applied equally between men and women. Some of the policies mandated by the Labour Law were not implemented, and the rights of women workers were not fulfilled, including the rights to menstrual leave, protection during pregnancy, and miscarriage leave[15].

The next major issue was the treatment of a significant number of women casual labors. The company did not have data on the number of casual labors, but it was estimated that around 900 people and $75 \%$ of them were women. Women casual labors did not get any rights as workers, except for the right to a minimal amount of daily wages (between IDR 50,000 to IDR 75,000 per day). They did not get health insurance, leave, etc., and were not considered as company labors. The number of women casual labors was far more than the number of permanent labors of the company, although the company did not have their numbers. It was because they were seasonally employed, and for jobs that were bought out to another party[16]. Some of the problems related to casual labors were the obligation to carry out inhuman work, discrimination, and the provision of wages below the Regional Minimum Wage (UMR) for daily wages, which violated and were not following the Labour Law. Women casual labors in carrying out their jobs had a dual role. They were the most vulnerable workers to adverse health impacts because $\mathrm{K} 3$ equipment is mostly unsuitable. In fact, in some plantations, women casual labors had to pay for K3 equipment which should be the company's obligation. Women casual workers also did not get social security facilities in the form of Health and Employment BPJS (Insurance). When they were sick, they had to use their funds or owed other parties[17].

The next issue is regarding the labors' right to become a member of a labor union. To fulfill the rights of employees to join labor unions, all permanent labors who work in the five research objects companies joined the workers' unions in their respective companies[18]. In general, the labors said that they did not understand the duties and functions of labors' unions and not much involved in labors' union activity. From this condition, it can be explained that the labors' union in the company were still not functioning and maximum as mentioned in Article 102 of Law No. 13 of 2003, and Law No. 21 of 2000 concerning Labours' Unions, including:

1. Democratically channeling the aspirations of members,

2. Developing skills and expertise of members

3. Fighting for the welfare of members and their families.

4. Involving in the Making of Collective Labour Agreements (PKB),

5. Settlement of industrial disputes,

6. Defending the rights and interests of union members.

From the research results, it is known that the involvement of workers in the Labour Union was only a formality, and labors unions had not yet carried out their duties as the unions. This condition made the Labours Unions unable to become a 
forum to fight for the members' interests and rights and to defend the rights of their members[19].

The issue is related to company regulations regarding labor and collective labor agreements which could be seen in the following explanation. For permanent labors of the company, in general, they were bound in a written work agreement, with clear rights and obligations, including the number of wages following the Aceh Province UMR that had been determined, namely, a minimum of IDR 2,950,000 (about 203 US\$/month)[20]. The minimum wage given was adjusted to the position and responsibilities in the company. The internal policies of the company, including the Collective Labor Agreement, were available only in the StateOwned Enterprises (SOEs). At the same time, private-owned enterprises did not have the policies (policies related to labor) and did not have collective labor agreements as required under the Law of Labour.

This condition will have an impact on the neglection of labors' rights. Some of the problems that have occurred includes demonstrations and strike in Aceh Tamiang at the beginning of 2020. It happened because the company was late in paying its labors' wages, and some labors were not paid their salaries as promised. The company did not provide a dispute resolution mechanism as a company regulation or regulated explicitly in a collective labor agreement so that when a dispute occurs, the company tried to escape responsibility.

Some of the research object companies, which have the company's rules and Collective Labour Agreement, generally only regulate the permanent workers. Having no regulation about casual workers, their position becomes vulnerable. The casual workers have a hefty workload because of the area of land, target tonnage, and long working hours, sociologically, and in terms of health, they are also isolated. They do not have proper housing, clean water, and their children's access to education is also quite far away, so it requires extra costs. However, health facilities are only provided for permanent workers, and various company facilities are provided for them[21]. The gap between permanent workers and casual workers is very far[22]. The various conditions show that the company has not fully implemented the principles of Business and Human Rights as agreed in the UNGPs, especially about the company's obligation to respect the rights of others. The company must avoid violations of the human rights of others. It must overcome human rights consequences that can be detrimental when running its business (Principle 15, UNGPs). The $12^{\text {th }}$ principle on the responsibility of business companies to respect human rights refers to the International Bill of Human Rights, and the International Labour Organization (ILO) Declaration on Fundamental Principles and Rights at Work.

The obligation to formulate a firm policy for the protection of human rights, including the rights of labors is expressly regulated in the $16^{\text {th }}$ UNGPs principle. As a basis for instilling their responsibility to respect human rights, business companies must convey their commitment to fulfill the responsibility through a policies statement which is:

a. approved at the highest level of the company;

b. notified by relevant internal and external experts;

c. stated about human rights expectations from the company for personnel, business partners, and other parties that are directly related to the activities, products, or services provided by the company;

d. available to the public and communicated internally and externally to all personnel, business partners, and other related parties;

e. available in operational policies and procedures that need to be embedded throughout the company.

The UNGPs $16^{\text {th }}$ principle has not been formulated in firm policy and has not been appropriately implemented by the company. To avoid the violations of human rights by the company in its business, a company needs to have Good Corporate Governance (GCG code) and the code of conduct, which must be obeyed by all elements relevant to the company. Having the codes, it will indirectly show the company's commitment to better corporate management, transparency, and respect for everyone's rights. However, even though the GCG code already exists, it does not necessarily guarantee that the company will or has implemented the GCG code properly. Plantation companies, especially privateowned enterprises, still do not have the GCG Code, so that a company firm commitment to implement the principle of governance cannot be seen.

Company reports, especially companies in the form of Public Legal Entities such as Limited Liability Companies (PT), which should ideally be published to the public, are also essential, as one 
indicator of the implementation of GCG. Research at the 5 Palm Oil Companies in Aceh Tamiang, Nagan Raya, and Aceh Singkil showed that not all plantation companies run GCG principles, including publicizing the report to the public to be accessed quickly and transparently. Only 3 out of 5 research object companies made public reports, while the other two companies did not make reports. In fact, in the Law on PT, a PT is obliged to make public reports, as a form of public accountability.

The documents and policies that clearly state the company's commitment are one of the conditions if the company has a concern to apply the principles of Business and Human Rights as agreed in the UNGPs, in particular, the $16^{\text {th }}$ principle. The $16^{\text {th }}$ principle stated that to strengthen the sense of responsibility for the respect of human rights. The companies must explain their commitment in the policy statement. Senior officials must approve it, published in the internal and external, as well as reflected in the company policies and procedures. In point, D said that "The policies should be available to the public and communicated internally and externally to all personnel, business partners and other related parties"; This principle is only implemented by three research object plantation companies, while the two other firms have not run it yet.

\subsubsection{Policies to Implementing Human Rights Due Diligence and Corporate Social Responsibilities}

Company obligation to carry out human rights due diligence is determined in the 17 th principle of UNCPs which stated that to identify, prevent, mitigate and account for how they cope with the impact of adverse human rights, business enterprises must undertake human rights due diligence. The process should include assessing the potential and tangible impacts of human rights, integrating them, and taking action. In principle, human rights due diligence is a mechanism for companies to observe human rights policies in companies, assess the impact of company activities on human rights, track and report performance, and the existence of a complaint mechanism for alleged human rights violations committed by companies, either directly or indirectly.

The five palm oil companies that became the object of research have not done human rights due diligence in particular. However, several indicators to meet the criteria for human rights compliance have been carried out, namely[23]:

\subsubsection{Conducting an Environmental Impact Analysis (AMDAL) in Land Clearance and Expansion}

From the results of research in 5 Palm Oil Plantation Companies, it is known that they have carried out an Environmental Impact Analysis, inland clearance, and expansion. An environmental impact analysis was carried out to assess the impact caused by the company during land clearance, both related to impacts on land cover, ecological impacts, and social impacts on the community. The environmental impact analysis was carried out by involving various stakeholders, including the Forestry and Environment Service, Plantation Service, affected community leaders, NGOs, and the AMDAL Assessment Team from academia as well as the technical team from the company[14]. AMDAL drafting carried out by the five companies did not involve experts on Human Rights, and few involved legal experts, so the AMDAL document almost did not mention the impact and efforts to anticipate the human rights violations by the company.

The UNGPs principle that is in line with the obligations of these companies is the 18th principle. The code stated that to measure human rights risks, business companies must identify and assess any potential or factual adverse human rights impacts in which they may be involved in their activities or business relationships. This process should:

a. Involve independent internal and external human rights experts;

b. Involve meaningful consultations with potentially affected groups and other relevant stakeholders appropriate to the business enterprise size and its operations' nature and context.

The four palm oil plantation companies, as the research objects, have not fully implemented the above principles.

1. The Availability of Environmental
Management System

Among the five plantation companies, it was demonstrated that three companies already have an environmental management system in the SOP for new land clearing and SOP for waste management. However, these SOPs have never been reviewed regularly. Meanwhile, the other two companies do 
not have a written environmental management system.

\section{The Availability of an Employment System}

The palm oil plantation companies already have an employment system. The system is implemented through a work contract between the company and the employee, regulating each party's rights and obligations[24]. The three companies already have a collective employment agreement (Perjanjian Kerja Bersama/PKB) prepared together with the company's Labour Union. Meanwhile, the other two companies only have work contracts but do not have a collective employment agreement. Apart from having a good employment system, the above three companies have an educational system to increase their employees' capacity as well as a social security system (BPJS Ketenagakerjaan) and a healthcare insurance system (BPJS Kesehatan). The five companies also have an Occupational Health and Safety system (Sistem Kesehatan dan Keselamatan Kerja/K3) and have specifically trained staff to manage this issue[18]. Although the system and personnel are in place, it is not yet socialized to various parties within the company, including casual daily laborers; thus, the workers' risks of work accidents and its settlement mechanisms are not well understood.

The company's employment system is only available for permanent workers, while a system that provides rights protection and fulfillment for casual daily workers is not yet available. This condition may result in the company's negligence of workers' rights.

Meanwhile, corporate social responsibility is not adequately regulated in the company's regulations. State-owned companies and national private companies are managed through their parent company (head office); therefore, the CSR benefits are not experienced locally, especially by communities in the plantation locations. Most palm oil plantation companies prepare CSR work programs through company activities with various social and environmental development goals, such as natural sustainability, employee welfare, public health, community economic development, and many more. The government has issued various policies related to the obligation of companies to carry out this responsibility. Some legal bases are mandatory for companies, including palm oil plantation companies in Indonesia. These legal bases include government regulations that mandate companies to take social and environmental actions, including Act No. 25 of 2007 regarding Investment,
Act No. 40 of 2007 regarding Limited Companies, and Act No. 32 of 2009 regarding Environmental Protection and Management. Also, the government issued Government Regulation No. 47 of 2012 regarding The Social and Environmental Responsibility of Limited Companies. Through these regulations, the government mandatorily assigns private companies to carry out their responsibilities to the surrounding community and environment. Private and state-owned palm oil plantation companies also have similar obligations. The obligations of state-owned enterprises (Badan Usaha Milik Negara/BUMN) are regulated through Minister of State-Owned Enterprise regulations.

Three out of five palm oil plantation companies did not manage CSR funds through its regional branches; however, it was managed by the company's head office. As a result, corporate social responsibility obligations were not implemented optimally. The five companies did not have specifically assigned staff to manage the CSR system and funds. As stated in the prevailing laws and regional regulations, the companies have not thoroughly carried out their mandate[25].

\subsubsection{Implementation of Remedies for Human Rights Violation}

For the Pillars of Remedies, the principle that must be considered by companies as contained in the UNGPs Principle 23 is as follows:

In all circumstances, a business enterprise must:

1. enable complaints to be swiftly responded to and remedies handled. Companies must establish or participate in grievance mechanisms at the operational level for affected individuals and communities.

2. ensure that effective grievance mechanisms are in place.

3. ensure the effectiveness of the procedure, nonjudicial grievance mechanisms, whether statebased or not, must be legitimate, accessible, predictable, fair, and transparent.

Companies have not yet fully implemented this principle. None of the companies that were studied had a complaint mechanism, either internal or external. Also, the companies did not have a Standard Operating Procedure (SOP) for dispute resolution. Dispute settlement mechanisms were only regulated between the company and its employee through the work contract. Meanwhile, 
dispute settlement mechanisms with communities surrounding the company site were not available. There were numerous problems, especially environmental-related, either related to waste management or other environmental issues. The disputes that occur with the community were resolved in a deliberative manner; however, many problems were not resolved correctly and fairly. Although agreed in the work contract, disputes with employees are often difficult to be resolved using the agreed mechanism. For example, a case of an employee at a palm oil plantation company in Aceh Tamiang, who had not received his payment when this research was conducted, has not been resolved[25]. The local government was not fully involved in the settlement and unable to solve the problem. Similar cases may continue to have impacts on employees and continue to violate their rights.

The company has never carried out environmental restoration as an impact of palm oil plantations, which resulted in a lack of water sources for the surrounding communities. Therefore, many communities surrounding the palm oil plantation area had difficulties in accessing clean water. The form of assistance by the company remained the provision of heavy machinery to build the village infrastructure[26]. Significant issues related to water availability for the residents were not a company priority to resolve.

\subsubsection{The Government's Efforts to Ensure the Implementation of Three Pillars of UNGPS}

The government's role in ensuring the implementation of Business and Human Rights principles are presented in Principles 1 to 8 of the UNGPs, i.e.: In fulfilling the protection duty, the state must:

a. Enforce laws that address or have an impact on the obligation of business enterprises to respect human rights, and periodically make judgments on the adequacy of these laws and address any deficiencies;

b. Ensure that laws and other policies governing the formation and ongoing operation of business enterprises, such as corporate law, and do not hinder but instead trigger business to respect human rights;

c. Provide useful guidance to business enterprises on how to respect human rights during their operational activities; d. Encourage and, when appropriate, require business enterprises to communicate their strategies on dealing with impacts on human rights.

The government is also obliged to implement the principles in Pillar 1 of Respect, i.e., the state must protect its territory from possible human rights violations by third parties, including by business entities. This principle requires precautionary measures, investigations, prepared regulations, punishment, and appropriate adjudication.

The state and government play a critical role in applying the principles of business and human rights in policy provision at the central, provincial, and regency levels. Also, the government carries out coaching and supervision functions regarding the implementation of human rights-related policies. The research demonstrates that regional governments, particularly the Nagan Raya and Aceh Tamiang Regency Governments, had committed to implementing business and human rights principles by issuing local regulations (Qanun), especially those related to corporate social and environmental responsibilities.

The existence of Qanun No. 7 of 2014 regarding The Implementation of Social and Environmental Responsibilities for Limited Companies in Aceh Tamiang Regency and Qanun No. 6 of 2019 regarding The Corporate Social and Environmental Responsibilities aims to bring about community welfare and environmental sustainability. Furthermore, it seeks to establish a synergistic relationship between the government and business entities in carrying out programs related to social and environmental aspects. Corporate social and environmental responsibility programs are limited to (1) micro, small, and cooperative business partnership programs, (2) social and environmental development programs, and (3) programs in the form of direct assistance to the community. These programs aim to improve social welfare, the community's economic strength, and maintain environmental functions for natural resources sustainability.

As a form of coaching and supervision effort, the Qanun regulates that companies need to submit annual reports on implementing social and environmental responsibilities to the regency government through the Corporate Social and Environmental Responsibility forum, an open platform that is accessible to the public. A copy of the report is submitted to the regional Parliament 
(DPRD) as part of its control function. The forum consists of elements from the regency government, regency Parliament (DPRK), academics, company associations, and community organizations. The forum was established to assist regency heads in coordinating and synergizing the government and private sector (company) programs.

The research shows that three palm oil companies have not implemented the social and environmental responsibility program in a planned manner. In general, the activities carried out were still direct assistance to the community or social service for grieving families. Also, the companies have not reported social and environmental responsibility activities because they do not have a specific division that manages CSR. Furthermore, the companies admit that their social and environmental responsibility program was not in line with the existing regulations and only limited to activities that indirectly impact the community. Meanwhile, based on the obtained data, the other two companies have not implemented social and environmental programs at the company's location.

According to the Qanun (regional regulations in Aceh), the definition of TJSP is a company's commitment to participate in sustainable economic development to improve life and environmental quality that is beneficial for the company itself, the local community, and society in general. Meanwhile, the definition of a company is a legal entity organization established according to statutory regulations or an agreement. The entity carries out business activities by raising capital, is engaged in the production of goods or services, and aims to generate profit. The Qanun also regulates that every company that carries out business activities in sectors related to natural resources must carry out corporate social and environmental responsibilities. Based on this understanding and considering the company's line of business, which was the research object, the companies should already have social and community-related activities that impact the community and the environment surrounding the companies. In general, these policies can be considered one of the local governments' commitments to fulfilling human rights. However, the attempt to ensure that companies implement business and human rights principles require more significant efforts, as mentioned in the UNGPs.

\section{CONCLUSION}

Palm oil plantation companies in Aceh have not adequately implemented the business and human rights principles. The company's internal regulations have not explicitly stipulated a commitment to implement the principles agreed in the UNGPs. The National Action Plan has demonstrated the Indonesian government's responsibility to apply the principles of business and human rights for Business and Human Rights in 2018; however, this commitment has not been fully implemented in palm oil plantation companies in Aceh. Regional plantation companies have not yet recognized the principles of business and human rights; therefore, their implementation remained minimal. However, based on the company's practices and policies, several principles have been implemented, especially by state-owned companies; although, still limited to policy provision and not yet fully practiced by companies in running their business.

Local governments have issued several policies that regulate the environmental protection and implementation of corporate social responsibility. However, local governments have yet to make significant efforts to ensure that palm oil plantation companies apply business principles and human rights in the form of mentoring, supervision, and dissemination. The local governments have not yet understood the principles of business and human rights and the National Action Plan on business and human rights, so they have no specific reference for mentoring and supervision.

It is recommended that companies formulate internal policies to apply the principles of business and human rights. Thus, in addition to achieving financial objectives, the company obtains social benefits by not violating human rights and providing maximum protection to various elements, both internal and external to the company, as well as the surrounding environment. Local governments are advised to prepare a Regional Action Plan for Business and Human Rights and formulate policies for implementing business and human rights principles in business companies, including plantation companies, which have distinct characteristics compared to other business companies. 


\section{REFERENCES}

[1] INFID, Kertas Kebijakan Menuju Implementasi Prinsip-Prinsip Panduan PBB tentang Bisnis dan HAM di Indonesia. Jakarta, 2016.

[2] J. G. Ruggie, Treaty Road Not Travelled, Ethical Corporation. 2018.

[3] I. J. Koenti, "Implementasi Pedoman PBB tentang Bisnis dan HAM Melalui Peraturan Perundang-undangan di Indonesia," J. Kaji. Huk., vol. 1, no. 1, 2018.

[4] Ibid, Halaman 57.

[5] Walhi Aceh, Laporan investigasi, Perkebunan Kelapa Sawit dan Kaitannya dengan Tingkat Kesejahteraan masyarakat Singkil. 2015.

[6] LBH Aceh, Laporan Tahunan Pelaksanaan Pendampingan. 2016.

[7] J. G. Ruggie, Protect, Respect \& Remedy: a Framework for Business and Human Right. Report of the Secretary-General's Special Representative on the human rights and transnational corporations and other business enterprises. 2008.

[8] R. Davis, "The UN Guiding Principles on Business and Human Rights and conflictaffected areas: state obligations and business responsibilities," Int. Rev. Red Cross J., vol. 94, no. 887, 2012.

[9] J. G. Ruggie, Report of the special representative of the UN secretary-general on the issue of human rights, and transnational corporations and other business enterprises. Business and human rights: Further steps towards the operationalization of the "protect, respect. 2010.

[10] W. Wagiman, Prinsip-prinsip Panduan untuk Bisnis dan Hak Asasi Manusia:Kerangka Perserikatan BangsaBangsa "Perlindungan, Penghormatan, dan Pemulihan". Jakarta: ELSAM, 2012.

[11] I. J. Koenti, Op. cit hal. 58. .

[12] A. Santika, "Potensi Pelanggaran HAM dalam Berbagai Kebijakan Negara yang Berhubungan dengan Hak Masyarakat Adat dalam Bidang Hak Sipol," makalah (Yogyakarta: Advanced Training on Indigenous Peoples' Rights untuk DosenDosen Pengajar Hak Asasi Manusia, Pusham UII bek. .

[13] Website Dinas Pertanian dan Perkebunan Aceh, "Data Perkebunan Aceh."

[14] Sarifuddin, “Askep PT Monopoli Raya,”
2020.

[15] Tiniasih, "BHL PT Monopoli Raya," 2020.

[16] Dewi, "BHL," 2020.

[17] A. N. Muhammad, "LSM Kempra," 2020.

[18] B. Andika, “Askep PTPN 1,” 2020.

[19] Darmawan, "Karyawan PT Mapoli Raya," 2020.

[20] Sarifuddin, “Askep PT MP,” 2020.

[21] Darmawan, "Anggota Serikat Pekerja PT MP," 2020.

[22] Mutia, "LSM Balaisyura Ureung Inong Aceh," 2020.

[23] F. Aksana, "PT Asian Agri," 2020.

[24] F. Laksana, "PT Asian Agri."

[25] E. Sardiyudi, "Kepala Bidang Perkebunan, Dinas Perkebunan Aceh Tamiang," 2020.

[26] Tommy, "Masyarakat di Lokasi Perkebunan,” 2020. 